\title{
The Factors Underpricing Level in The Companies Conducting Initial Public Offering At Indonesia Stock Exchange
}

\author{
Yohandes Rabiqy $^{1^{*}}$ and Yusnaidi ${ }^{2}$ \\ ${ }^{1,2}$ Teuku Umar University, Meulaboh, Indonesia
}

\begin{abstract}
The purpose of this research is to examine and analyze the influence of of the variables Current Ratio, Firm Size, Financial Leverage, and Return on Equity to Underpricing level. This research used the Initial Public Offerings companies which was listed its stock to Indonesian Stock Exchange. The data that is used at this research was taken from the annual published financial report of each company. The population in this research is companies that were listed to Indonesian Stock Exchange during period 2012 through 2016. The amount of population was 115 companies. Based on certain criteria, there are 62 samples from population. Method of multiple linear regressions on panel data approach using Common Effect Model (The Pooled Least Square). Simultaneous test in hypotesis results shows that Current Ratio, Firm Size, Financial Leverage, and Return on Equity have a significant effect on the Underpricing level of Initial Public Offerings companies. Partial test (t-test) in hypothesis result shows that Firm Size have a negative and significant effect on the Underpricing level of Initial Public Offerings companies that listed in Indonesian Stock Exchange. Current Ratio, Financial Leverage, and Return on Equity have a negatif and insignificant on the Underpricing level of Initial Public Offerings companies that listed in Indonesian Stock Exchange.
\end{abstract}

Keywords: Common Effect Model, Financial Leverage, Firm Size, Return on Equity, Underpricing Current Ratio

\section{INTRODUCTION}

This section describes the background of the study that supported with information from existing literatures, underlines the issues and states the research objectives. Many businesses think that by making the company as one of the company that Go Public will enhance the company's image. This thinking is not completely wrong, because the fact shows that most of the best companies in Indonesia are the open companies or the company that Go Public.

The tendency can be found in both large company and small company. Nevertheless, the greatest tendency can be found in small-medium company, sometimes the companies want to be strong while they did not want to release the stock to the public. Then, the companies attempt to make the brand to be strong in the gobal market. It is realized by making the company Go Public or do an IPO.

\footnotetext{
* Corresponding author. Email address: $\underline{\text { rabiqy85@ gmail.com }}$
} 
The additional capital from public for the company is also one of the factors that company to sell the stocks to the public in order to receive large profit or fund directly and not staged. The people who enter the possession or ownership is usually not interested to include into the management so that the interest of the majority of the company owner can run stable. To create the openness to the public. The openness is created because of the tight regulation at the capital market, therefore everything is transparent. The transparent here means there's no hidden information to the public. The dividend payment based on the profit to give the value of a company. Because the companies that Go Public have the high prestige image in the public and also the company's market value can be known.

More the companies are doing the IPO, there will be an increase in the number of the companies that listed on the Indonesian stock exchange resulted in an increased number of shares in the stock market so that investors can pick stocks to be bought. This circumstances would require a specific strategy to buy the stocks if it can be selected in investing and can generate the profits.

The emiten company expects through the IPO activities will improve the company's prospect for expansion will be done and an improving outlook for the company will make the stocks price offered is higher. In additional, the company's capital can increase through the go public activities and also create a public market where the founder and the other stockholder to convert the majority of their stocks in cash immediately at a same time in the future, hence increasing the publicity that plays a cmplementary role for most huge companies.

Eventhough the needs of the additional capital for a company can be fulfilled through many ways, by selling the new stocks is one way. If a company has a legal entity such as a Limited Company wants to seek the additional funds for business expansion, the company was able to raise the funds through some of the following alternatives:

- Applying for a loans to banks, by finding the short-term loans (through the financial market).

- Issuing bonds, which is a loan debt form for long-term debt or issuing stocks.

Issuing bonds or stocks made through the capital markets. If the companies chooses the issuing stocks, then the company should prepare the Go Public process.

The problem can be faced by the companies when doing the IPO in the capital market is the determination of the initial offering price. On one hand, the company wants to set the high prices in order to gain the acceptance of result of high proceeds. On the other hand, the expensive stock prices influences investor intensions to buy that stocks, and the expensive stock prices also affect the offering stocks less interesting because the investors want to get the initial return from the differences between the stock prices in the secondary market and the stock purchase in the primary market, therefore, this circumtances are not favorable for the issuers, because they sacrifice the returs that should be obtained. The precense of initial return indentify the underpricing phenomenon in the primary market.

If the stock prices in the primary market lower than the stock prices in the secondary market at the first day, the underpricing phenomenon will be happened. The underpricing of the stock prices depend on demand and offer on the first day that stocks traded on the exchange. The price can be used from the offering price (IPO price) or closing price on the first day of the transaction in the secondary market. If the price that offered to the public on the first day is Rp395 per stocks 
The Factors Underpricing Level in The Companies Conducting Initial Public Offering At Indonesia Stock Exchange

and on the first day the stocks are transactioned with the closing price is Rp550 per stocks, therefore the stocks price is assumed the underpricing. It means the reasonable price is the demand and offer is $\mathrm{Rp} 550$.

The following data is the price of five companies that experience underpricing from 64 samples which is used on 2012 to 2016.

\begin{tabular}{clccccc}
\hline No & $\begin{array}{c}\text { Company } \\
\text { Code }\end{array}$ & $\begin{array}{c}\text { IPO } \\
\text { Price } \\
(\mathbf{R p})\end{array}$ & $\begin{array}{c}\text { Closing } \\
\text { Price } \\
(\mathbf{R p})\end{array}$ & CR (\%) & $\begin{array}{c}\text { DAR } \\
(\boldsymbol{\%})\end{array}$ & $\begin{array}{c}\text { ROE } \\
(\%)\end{array}$ \\
\hline 1 & SRAJ & 120 & 200 & 0,717 & 24,84 & 0,724 \\
\hline 2 & ALTO & 210 & 315 & 214,3 & 41,8 & 8,56 \\
\hline 3 & NAGA & 180 & 305 & 7,25 & 87,56 & 2,12 \\
\hline 4 & ASMI & 270 & 405 & 633,11 & 60,83 & 11,96 \\
\hline 5 & DPUM & 555 & 825 & 4,99 & 21,36 & 6,44 \\
\hline
\end{tabular}

The table above describes the underpricing conditions in five companies that happened in 2011-2015 where the IPO price that offered on the first day in the primary market is lower than closing price stocks on the first day is traded in the secondary market. The investors who buy the stocks in IPO always want the price stocks increased in the secondary market, therefore the investors obtain the stocks return. The grade of stocks return on the first day is known as initial return. However, because of the underpricing condition which happened in Indonesia's capital market as seen on the table 1.2, it is definitely detrimental the company that go public, because the fund that obtained from the public is not maximal.

Generally, the occurance of this condition caused by a variety of factors, both through financial ratio (CR, DAR, ROE) and non-financial (stock price, total assets owned, etc).

The underpricing phenomenon occures because of a variety factors, first of all underpricing is deliberately done to attract investors in the primary market. In addition, to provide benefits to the underwriter, and secondly, the asymmetry information. The assymetry may occur between issuers and underwriters as well as between investors. In order to reduce the assymetry information, therefore the company conducted the issuance of a prospectus. The prospectus detailing the information and material facts about the public offering of the issuer in the form of the financial and non-financial information (Suyatmin and Sujadi, 2006).

The firm size factor is one of the factor which plays an important role in helping to convince the investors to assess the stock price, therefore the possibility of underpricing can be minimized. This case also investigated by Islam dkk (2010), Yolana and Martani (2005), Hapsari and Mahfud (2012) found that the firm size positive significant effect on underpricing.

The financial leverage is also one of the factors that influence, such the research that conducted by Isfattun and Hatta (2010), Wulandari (2011) that stating the financial leverage is effected positive significant on the level of underpricing.

In addition, the ROE is also one of the factors that effected the underpricing level. The research by Yolana and Martani (2005), Hapsari Mahfud (2012)found that the ROE factor effects positive significant on the level underpricing. The research conducted by Isfattun and Hatta (2010) discovered another result about 
ROE factor, they discovered that ROE is not effected significantly on the initial return.

\section{LITERATURE STUDY}

The stock market is the market in which shares of publicly held companies are issued and traded either through exchanges or over-the-counter markets Also known as the equity market, the stock market is one of the most vital components of a free-market economy, as it provides companies with access to capital in exchange for giving investors a slice of ownership in the company. The stock market makes it possible to grow small initial sums of money into large ones, and to become wealthy without taking the risk of starting a business or making the sacrifices that often accompany a high-paying career.

Organized and regulated financial market where securities (bonds, notes, shares) are bought and sold at prices governed by the forces of demand and supply. Stock exchanges basically serve as primary markets where corporations, governments, municipalities, and other incorporated bodies can raise capital by channeling savings of the investors into productive ventures; and secondary markets where investors can sell their securities to other investors for cash, thus reducing the risk of investment and maintaining liquidity in the system. Stock exchanges impose stringent rules, listing requirements, and statutory requirements that are binding on all listed and trading parties.

\subsection{Stock Exchange Function}

Rivai, et al. (2013:97-98) said that capital market has several functions as belows :

1. Provide a source of financing (long-term) for the business while enabling optimal resource allocation

2. Provide an investment vehicle for investors while allowing diversification efforts;

3. Provide a leading indicator for the country's economic trends.

4. Distribution of corporate ownership into the general public;

5. Provide an opportunity to have a healthy company and prospects;

6. Create jobs were interesting;

7. Creating liquidity of trading in securities;

8. The spread of ownership, openness and professionalism as well as creating a good business climate.

\subsection{Go Public}

Going public and offering stock in an initial public offering represents a milestone for most privately owned companies. A large number of reasons exist for a company to decide to go public, such as obtaining financing outside of the banking system or reducing debt. Furthermore, taking a company public reduces the overall cost of capital and gives the company a more solid standing when negotiating interest rates with banks. This would reduce interest costs on existing debt the company might have.

The main reason companies decide to go public, however, is to raise money a lot of money - and spread the risk of ownership among a large group of shareholders. Spreading the risk of ownership is especially important when a company grows, with the original shareholders wanting to cash in some of their profits while still retaining a percentage of the company. 
The Factors Underpricing Level in The Companies Conducting Initial Public Offering At Indonesia Stock Exchange

Table 1 The difference between Go Public Company and Non Go Public Company table

\begin{tabular}{clll}
\hline No & \multicolumn{1}{c}{ Aspect } & Non Go Public & \multicolumn{1}{c}{ Go Public } \\
\hline 1 & Minimum disclosure requirements & Not Absolute & Absolute \\
\hline 2 & Investor & Limited & More than 300 Investor \\
\hline 3 & Financial Report (reguler or insidentil) & Not Absolute & Absolute \\
\hline & $\begin{array}{l}\text { Segmented between owner and } \\
\text { managerial }\end{array}$ & Low & High \\
\hline 5 & Ownership & Low & High \\
\hline 6 & Managerial & Not Figure & Figure \\
\hline
\end{tabular}

\subsection{Initial Public Offering}

An initial public offering (IPO) is the first time that the stock of a private company is offered to the public. IPOs are often issued by smaller, younger companies seeking capital to expand, but they can also be done by large privately owned companies looking to become publicly traded. In an IPO, the issuer obtains the assistance of an underwriting firm, which helps determine what type of security to issue, the best offering price, the amounts of shares to be issued and the time to bring it to market.

IPOs are introduced to the market by an underwriting investment bank, which aids the issuing company by soliciting potential investors. In addition, the underwriter helps the issuing company to settle on the price at which the stock should be offered to investors. IPOs represent the first time an issuing company will financially benefit from the public sale of its stock. Following the IPO, shares trade between buyers and sellers on the open market, whereby the underlying company receives no compensation.

\subsection{Underpricing}

An initial public offering (IPO) is the first time that the stock of a private company is offered to the public. IPOs are often issued by smaller, younger companies seeking capital to expand, but they can also be done by large privately owned companies looking to become publicly traded. In an IPO, the issuer obtains the assistance of an underwriting firm, which helps determine what type of security to issue, the best offering price, the amount of shares to be issued and the time to bring it to market. An IPO is also referred to as a public offering. When a company initiates the IPO process, a very specific set of events occurs. The chosen underwriters facilitate all of these steps.

\section{RESEARCH METHODOLOGY}

The current ratio is a liquidity and efficiency ratio that measures a firm's ability to pay off its short-term liabilities with its current assets. The current ratio is an important measure of liquidity because short-term liabilities are due within the next year. 


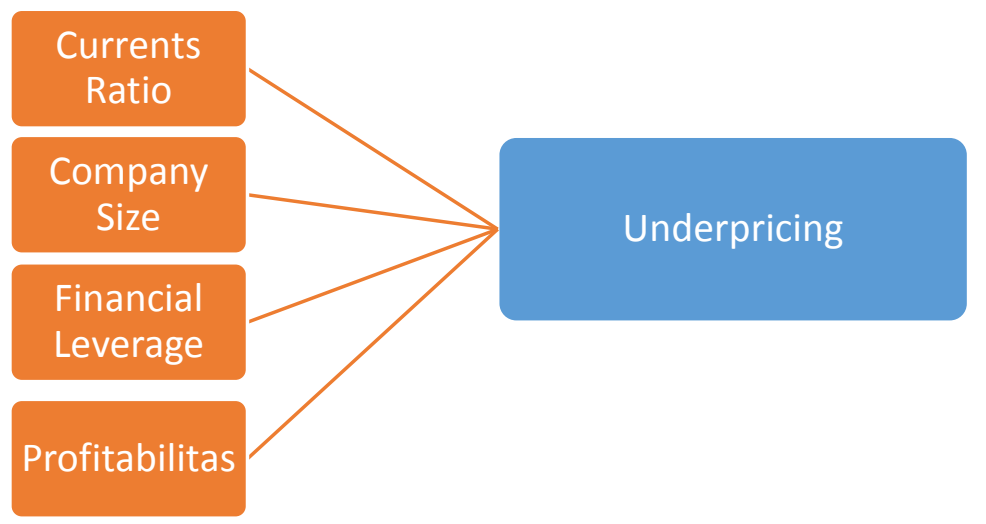

For the size of the companies in this research is a reflection of the size of the companies that appear in the value of total assets of the company. With the growing size of the company, there is a tendency that more investors are paying attention to the company. This is because large companies tend to have a more stable condition. This stability to attract investors to own shares in the company. This condition is a cause for rising share prices of companies in the capital market. Investors have great expectations vis large enterprises. Insvestor expectation of acquiring the dividend from the company. Increased demand for the company's stock will be able to spur the increase in stock prices in the capital market (Shofwatul, 2011).

The level of leverage describes the risk level of the company measured by comparing total liabilities to total assets owned by the company. The higher the level of leverage of a company, the higher the level of uncertainty factors will negatively affect the company so that the initial return (Sulistio, 2005). This is also supported by Firth and Smith in Trisnaningsih (2005) that financial leverage is a high level of obligations to make the company's management becomes more difficult to make a firm prediction.

Return on equity (ROE) is a ratio that is often used by shareholders to assess the performance of the company concerned. ROE measures the level of return on capital of the company. Considerations include variables ROE for the company's profitability provides information to outside parties regarding the operational effectiveness of the company. In this research, the variables represented profitability with ROE assumed as investors' expectations for funds invested in the company's IPO. The greater profitability (ROE), then the investor would be interested in buying or looking for a company's stock IPO because hope in the future will get large returns on their ownership. It This suggests the increase in the offer price of shares traded on the secondary market caused the demand for the stock price to rise (Yolana and Martani, 2005).

\subsection{Research Hypothesis}

Based on the conceptual framework that has been described, the hypothesis of this research is the currentratio,the size of the company(firmsize), financial leverage and profitability (ROE) simultaneously and partially significant effect on 
The Factors Underpricing Level in The Companies Conducting Initial Public Offering At Indonesia Stock Exchange

the level of underpricing shares when the company made an Initial Public Offering (IPO) at the Indonesian stock Exchange (BEI).

\section{METHODS}

Based on the formulation of the problem and research objectives, this research is the kind of associative research with the aim to determine the relationship between two or more variables. This research aimed to analyze the influence of the currentratio,the size of the company(firmsize), financial leverage and profitability (ROE) to underpricing.

\subsection{Operational Segment}

Operational segment of this research are as follows:

a. Dependent Variable (Variable Bound) in this research was Underpricing.

b. Independent Variables (Variables) this research consist of Current Ratio (X1), Company Size (X2), Financial Leverage (X3), profitability of the Company (X4).

c. The object of this research is a company whose shares suffered underpricing at the time of IPOin Indonesia Stock Exchange period January 2012 - December 2016

\subsection{Independent Variable $(X)$}

\subsubsection{Current Ratio (X1)}

Current ratio is the ratio used to measure a company's ability to meet current liabilities from current assets owned by the company. The higher this ratio, means the greater the company's ability to meet short-term financial obligations that negatively affect the level of underpricing. The calculation of this ratio is:

$$
\text { Current Ratio }=\frac{\text { Current Assets }}{\text { Current Liabilities }}
$$

\subsubsection{Company Size}

In general, the size of the company can be seen from the total assets of the company in the last year before the company's listing. Company size is measured by calculating the natural logarithm $(\ln )$ in total assets last year before the company's listing. The higher this ratio, the higher the level of investor confidence given to the company that negatively affect the level of underpricing.

$$
\text { Size }=\text { natural logarithm of total assets }
$$

\subsubsection{Financial Leverage (X3)}

Degree ofcan leverage describe the level of risk of the company measured by comparing the company's total liabilities to total assets owned by the company. The higher the level of leverage, the higher the level of uncertainty will be the company that makes the management of investor is more difficult to make predictions this company means the ratio of positive effect on the level of underpricing. Calculations:

$$
\text { Debt to Total Assets Ratio }=\frac{\text { Total Debt }}{\text { Total Assets }}
$$




\subsubsection{Profitability of the Company (X4)}

ROE is a commonly used ratio of shareholders to assess the performance of the company concerned. This ratio measures the ability of the company makes a profit available to shareholders of the company. The higher this ratio, investors will be more interested to embed a number of shares in the company because the company considered more capable and to meet the expectations of investors will profit earned on funds invested in the company, this means that this ratio had a negative impact on the level of underpricing. ROE can be used to measure the following formula:

$$
R O E=\frac{\text { Net Profit After Tax }}{\text { Shareholder's Equity }} \times 100 \%
$$

\subsubsection{Dependent Variable}

Dependent Variables in this research is underpricing shares, measured by initialreturn. Initial returns are the benefits of shareholders because of the difference in price of shares purchased in the market at the prime time of the IPO stock price on the first day in the secondary market.

\subsubsection{Population and Sample}

The population in this research are all companies that gopublic in Indonesia Stock Exchange (BEI) in the period 2012-2016. Total population earned during the period amounted to 118 companies. The sampling method using certain criteria. The criteria are as follows:

1. The Company performs its IPO during the period 2012-2016.

2. The company is experiencing underpricing in which the stock price lower than the IPO price on the first day in the secondary market.

3. Publishes Financial Statements for the period 2012-2016 with complete data in accordance with that required in this research. Date of listing on the Stock Exchange and the IPO price available. The financial statements used are the financial statements obtained from BEI.

4. Data's closing price(closingprice), total assets, liabilities and equity are listed in IDX Fact Book on the Stock Exchange.

Based on the sampling criteria, the obtained sample as many as 62 firm votes.

\section{RESULTS}

The descriptive analysis describes the phenomenon or characteristics of the data. The purpose of descriptive analysis is to make it easier to read the data and understand the meaning. The data processed in the form of descriptive statistics will display the characteristics of the sample that used in this research includes the number of sample $(\mathrm{N})$, the average of the sample (mean), minimum and maximum, and standard deviation. The description in this research consists of five variables; current ratio, size of firm, financial leverage (DAR), return on equity (ROE), and underpricing, that shows in the table below: 
The Factors Underpricing Level in The Companies Conducting Initial Public Offering At Indonesia Stock Exchange

Table 2 Descriptive statistic result table

\begin{tabular}{lccccc}
\hline & Underpricing & $\begin{array}{c}\text { Current } \\
\text { Ratio }\end{array}$ & $\begin{array}{c}\text { Size of } \\
\text { Firm }\end{array}$ & $\begin{array}{c}\text { Financial } \\
\text { Leverage }\end{array}$ & ROE \\
\hline Mean & 24.82592 & 264.7296 & 27.61075 & 47.73995 & 17.47621 \\
\hline Median & 14.21000 & 166.9100 & 27.74500 & 47.96500 & 11.85000 \\
\hline Maximum & 95.08200 & 1273.090 & 30.68000 & 89.30664 & 201.1700 \\
\hline Minimum & 1.080000 & 33.40000 & 20.31000 & 7.560000 & 0.160000 \\
\hline Std. Dev & 22.30132 & 267.3955 & 1.404158 & 23.81435 & 29.71917 \\
\hline Observation & 62 & 62 & 62 & 62 & 62 \\
\hline
\end{tabular}

The appendix table above describes the amount data that used in this research is approximately 62 samples of data which is taken from the company's annual financial statement that listed on the Indonesia stock exchange that is accessed from the website www.idx.co.id

a. Current ratio has the average (mean) aproximately 264.7296, the minimum value approximately 33.4 was obtained by PT. Bali Tower Indo Sentra, Tbk. In 2014, the maximum value approximately 1273,090 was obtained PT. Mitra Keluarga Karya Sehat, Tbk. In 2015, and the standard deviation approximately 267.3955 .

b. The size of firm has the average (mean) aproximately 27.61075 , the minimum value approximately 20.31 that was obtained by PT. Bali Tower Indo Sentra, Tbk. in 2014, the maximum value approximately 30.68 was obtained by PT. Salim Ivomas Pratama, Tbk in 2011 and the standard deviatio appoximately 1.404158 .

c. The financial Leverage (DAR) has the average (mean) approximately 47.73995, the minimum value approximately 7.56 was obtained PT. Victoria Investama, Tbk. in 2013, the maximum value approximately 89.30664 was obtained by PT. Bank Yudha Bhakti, Tbk. in 2015, and the standard deviation approximately 23.81435.

d. The ROE (Return on Equity) has the average (mean) approximately 17.47621, the minimum value approximately 0.16 was obtained by PT. Intan Baruprana Finance, Tbk. in 2014, the maximum value approximately 201.17 was obtained by PT. Alkindo Naratama, Tbk. in 2011 , and the standard deviation appromately 29.71917.

The underpricing has the average (mean) approximately 24.82592, the minimum value 1.08 was obtained by PT. Sri Rejeki Isman, Tbk. in 2013, the maximum value appromately 95.082 was obtained by PT. Surya Essa Perkasa, Tbk. in 2012, and the standard deviation approximately 22.30132 .

\subsection{Classic Assumption Test}

\subsubsection{Normality Test}

In this research, the normality test of the residuals using the Jarque-Bera (J-B) test, with a significance level used. The basic desicions is based on the probability value from the J-B statistic, with the following provisions:

1. If the probability value more than 0.05 , therefore the normality assumption is met.

2. If the probability value less than 0.05 , therefore the normality assumption is not met. 
The probability value of the J-B statistic is 0.054158 . Because of the probability value is 0.054158 , more than the significance level $(0.05)$. Therefore, the normality assumption was met.

\subsection{Hypothesis Test}

On the hypothesis test, The partial regression coefficient significance testing will be performed comprehensively and simultaneously (F-test), The partial regression coefficient significance testing will be performed individually ( $t$-test) and determination coefficient analysis.

\subsubsection{F-test}

The known probability value of the F-test is 0.0284 . Because of the p-value (0.0284) less than the significance level is 0.05 , therefore the null hypothesis is rejected and the alternative hypothesis is accepted. In clonclusion, current ratio, firm size, financial leverage, and the $\mathrm{ROE}$ is significantly effected to the underpricing stock level when the company doing the IPO in the Indonesia stock exchange.

\subsubsection{T Test}

Test the significance of the partial effect is a test to see significant or not, the influence of each independent variable on the dependent variable. Decision making can be done by comparing the probability value or Sig. with a value of significance level, ie. If the value of the probability significance level used in this research, the value of partial regression coefficient. This means that the effect of independent variables to variable stock price is not statistically significant at the 5\% significance level. However, if the probability value <significance level is used, then the value of partial regression coefficient. This means that the influence of independent variables on the stock price variables are statistically significant at the 5\% significance level. Another way of decision-making of the hypothesis can be done by comparing the value of the test statistic to the critical value based on the distribution table. Before calculating the critical value, the first calculating the value of degrees. Here's the formula for calculating the value of degrees of freedom.

Degrees of freedom $=n-\mathrm{k}$

Note that the stated number of elements in the sample, while a number of variables. An unknown number of elements in a sample of 44 and the number of variables is 5 , so the degree of freedom is. The significance level used was $5 \%$, so the critical value with 57 degrees of freedom and a level of significance based distribution table is. \pm 1.67203 .

The following decision rule based on the test of the hypothesis (Gio, 2015: 61):

If $\left|T_{t}\right| \leq\left|t_{\text {Critical }}\right|$, then $H_{0}$ is received and $H_{1}$ rejected

If $\left|T_{t}\right|>\left|t_{\text {Critical }}\right|$, then $H_{0}$ is rejected and $H_{1}$ accepted

\section{DISCUSSION}

\subsection{Effect of Current Ratio (CR) to the level Underpricing}

Results of this research indicate an increase or decrease in the Current Ratio during the research period did not affectthe level Underpricing. significantly Partially it can be seen that the CR and no significant negative effect on stock prices. The higher the CR, therate underpricing will decline, but the effect shown is not statistically significant or insignificant, since the possibility of the investor 
as having excess funds paid little attention to the information about current ratio a company'swhen doing an IPO. Variable current ratio does not affect the level of underpricing shares as investors judged that the company's goal go public is tolongterm goals, so the liquidity of companies that demonstrate the company's ability to repay short-term obligations less attention investors. This is according to research conducted by Hapsari and the Mahfud (2012), the results of the research showed avariable current ratio but notnegative effect significanton the level of underpricing shares.

\subsection{Effect of Size of Firm towards Underpricing}

Results of this research indicate an increase or decrease in the variable size of the firm during the research period affect the level of underpricing shares significantly. Partially it can be seen that the SIZE a significant negative effect on the level of underpricing shares. The higher the SIZE variable, then the level of underpricing of shares will decline. The high size of the firm can be used as a benchmark by investors in viewing quality companies because large companies tend to have a stable condition, the stability will attract investors to own shares in the company. This is consistent with the results of research conducted by Boubaker and Mezhoud (2011), Yolana and Martani (2005), and Wulandari (2011), but in contrast to the results of research on Islam et al.(2010) who found that the variable size of the company giving positive and significant impact on the level of underpricing shares.

\subsection{Effect of Financial Leverage (DAR) on the level Underpricing}

Results of this research indicate an increase or decrease in financial leverage (DAR) during the research period did not affect the level of underpricing shares significantly. Partially it can be seen that the DAR and no significant negative effect on the level of underpricing shares. The use of high debt in the company's operations will lead to disinterest of investors to invest. The higher level of financial leverage of a company, the higher the level of risk faced by the company, which means the higher the leverage, the higher the uncertainty factor will be the company. Accordingly, investors will be more selective in choosing shares to be purchased and avoid investing in companies with high DAR value so the impact of the uncertainty of the price of a stock. This is according to research conducted by Junaeni and Agustian (2013).

\subsection{Effect of Corporate Profitability (ROE) on the level Underpricing}

Results of this research indicate an increase or drop in the company's profitability (ROE) during the research period did not affect the level of underpricing shares significantly. Partially it can be seen that the ROE is negative and not significant to the level of underpricing shares. ROE is a ratio that provides information to investors about how much the return on capital of the company resulting from the performance of companies that generate profits. The greater the value of ROE, the expected rate of return is also a large investor, which means the company considered more profitable. Prospective investors will consider the percentage of the profitability of the company before making their investment decisions so that the lower the uncertainty value, which will also reduce the level of underpricing the company. The results support the research that has been done Isfaatun and Hatta (2010). 


\section{CONCLUSION}

\subsection{Conclusions}

Based on the results of research and discussion that has been stated previously, the conclusions of this research are as follows:

1. This research aims to identify and analyze the factors that influence simultaneously on the level of underpricing shares at the time of its initial public offering in the Indonesia Stock Exchange, The results showed that simultaneous, currentratio,the size of the company(firmsize), financial leverage and profitability (ROE) significantly affects the level of underpricing shares when the company made an Initial Public Offer (IPO) 2011-2015.

2. This research aims to identify and analyze the factors that influence partially on the level of underpricing shares at the time of its initial public offering in the Indonesia Stock Exchange. The results showed that partially, size of firm a significant negative effect on the level of underpricing shares. While the current ratio, financial leverage (DAR) and profitability (ROE) and no significant negative effect on the level of underpricing shares when the company made an Initial Public Offer (IPO) 2011-2015.

\subsection{Recommendations}

Based on the findings, the researchers tried to provide suggestions and input for the company, investors as well as further research as follows:

1. Given this research, the company is expected to pay more attention to the factors that affect the level of underpricing in order to reduce the risk of underpricing current share public offering premiered at the Indonesia Stock Exchange, so that the funds expected from the opening can be obtained with a maximum investment.

2. For investors, it is expected to be much more selective in choosing the company that will be a place to invest. One consideration that can be drawn from this research is that the investor can see that the company has good growth rates to manage the company. Thus, investors have more consideration for investment decisions.

For further research, it is advisable to use more of the other independent variables outside the variable currentratio,the size of the company(firmsize), financial leverage and profitability (ROE). Future studies are also advised to do research per-sector companies with the characteristics of a more diverse, so the results obtained can represent to be concluded by comparing each sector companies listed on the Indonesia Stock Exchange, and further research is also expected to conduct research usingdata series time up to date/ the latest, so that the results will also be more accurate.

\section{References}

Brealey, R. .A., Stewart, C. M., \& Allen, F. (2006). Corporate Finance (8th Edition). New Work: McGraw Hill.

Brealey, R. A., Stewart, C. M., \& Alan, J. M. (2007). Dasar-dasar Manajemen Keuangan Perusahaan (Jilid Pertama, Edisi Kelima). Jakarta: Erlangga. 
The Factors Underpricing Level in The Companies Conducting Initial Public Offering At Indonesia Stock Exchange

Boubaker, A., \& Mezhoud, M. (2011). Determinants of The Components of IPO Initial Return:Paris Stock Exchange. International Journal of Accounting and financial Reporting, 1(1), 190-211.

Ghozali, I. (2012). Aplikasi Analisis Multivariate dengan Program SPSS. Semarang: Badan Penerbit Universitas Diponegoro.

Hapsari, V. A., \& Mahfud, M. K. (2012). Analisis Faktor-faktor yang Mempengaruhi Underpricing Saham Pada Penawaran Umum Perdana di BEI Periode 2008-2010. Diponegoro Journal of Management, 1(1), 1-9.

Isfattun, E., \& Hatta, A. J. 2010. Analisis Informasi Penentu Harga Saham Saat Initial Public Offering. Jurnal Ekonomi dan Bisnis, 15(1), 66-74.

Junaeni, I., \& Agustian, R. 2013. Analisis Faktor-faktor yang Mempengaruhi Tingkat Underpricing Saham Pada Perusahaan yang Melakukan Initial Public Offering di BEI. Jurnal Ilmiah WIDYA, 1(1), 52-59.

Mayo, H. B. (2008). Investments: An Introduction. Canada: Thomson SouthWestern.

Rivai, H. V., Modding, H. B., Veithzal, A. P., \& Mariyanti, S. M. (2006). Pasar Modal dan Manajemen Portofolio. Jakarta: Erlangga.

Shofwatul, A. (2012). Pengaruh Struktur Aktiva, Ukuran Perusahaan dan Profitabilitas Terhadap Struktur Modal. [Skripsi]. Universitas Diponegoro.

Sulistio, H. (2005). Pengaruh Informasi Akuntansi dan Non Akuntansi Terhadap Initial Return: Studi Pada Perusahaan yang Melakukan Initial Public Offering di Bursa Efek Jakarta. Simposium Nasional Akuntansi VIII Solo, 8799.

Suyatmin., \& Sujadi. (2006). Faktor-faktor yang Mempengaruhi Tingkat Underpricing Pada Penawaran Umum Perdana di Bursa Efek Jakarta. Jurnal Ekonomi BENEFIT, 10(1), 11-32.

Trisnaningsih, S. (2005). Analisis Fakor-faktor yang Mempengaruhi Tingkat Underpricing pada Perusahaan yang Go Public di Bursa Efek Jakarta. Jurnal Akuntansi dan Keuangan, 4(2), 195-210.

Van Horne, J. C., \& Machowicz, Jr, J. M., (2008). Fundamentals of Financial Management (13th Edition). United Kingdom: Pearson Education.

Walsh, C. (2012). Key Management Ratios (Edisi Keempat). Jakarta: Erlangga.

Widjaja, G., \& Risnamanitis, W. (2009). Go Public dan Go Private di Indonesia (Edisi Pertama, Cetakan Pertama). Jakarta: Kencana Prenada Media Group.

Wulandari, A. (2011). Analisis Faktor-faktor yang Mempengaruhi Tingkat Underpricing Pada Penawaran Umum Perdana (IPO). [Skripsi]. Universitas Diponegoro. 